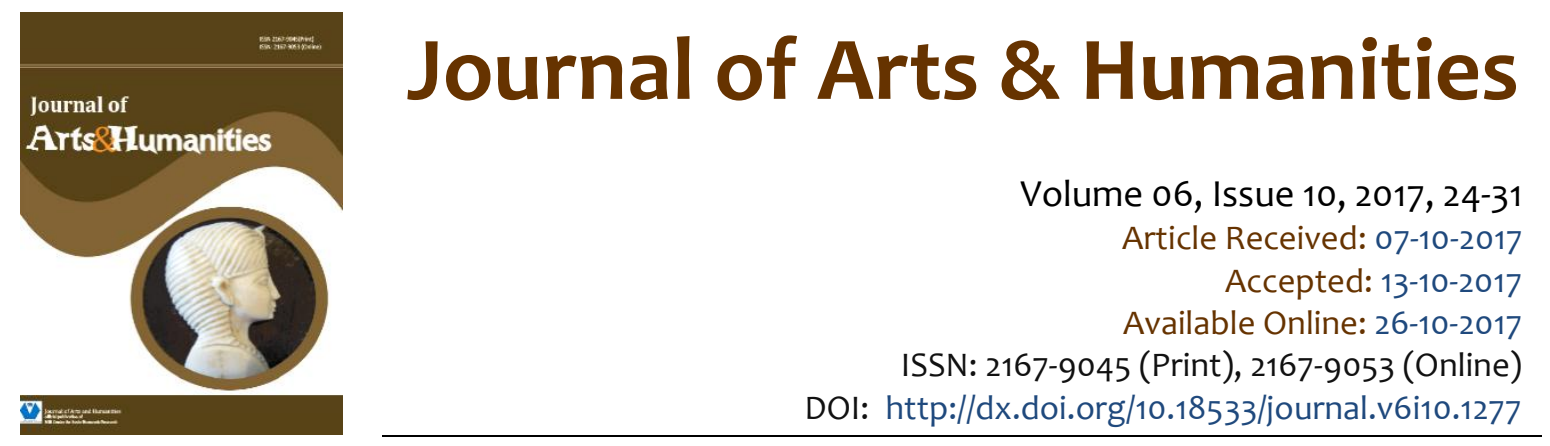

\title{
The Benefits of Mix Farming Agribusiness to Strengthen Food Sustainability of the Farmer Households at Agrotourism Areas
}

\author{
Imam Santosa', Agus Suyanto²
}

\begin{abstract}
This research aims at examining the benefits of mix farming agribusiness to strengthen food sustainability of poor farmer households at agro-tourism areas. The research is designed using a case study method based on qualitative and quantitative approach. This research is intentionally conducted in Karangreja Sub-district, Purbalingga Regency of Central Java Province. Based on the research results, it shows that mix farming agribusiness may provide the practical and economic benefits to strengthen food sustainability of the 12 adopting farmer households as the research respondents. High practical benefits are directly shown on 83 percent of respondents who find it easy to provide food materials consisting of vegetable and side dish (cat fish). Furthermore, the development of mix farming agribusiness also directly provides practical benefits to 67 percent of respondents in obtaining several food types, including corn and chicken. The other research results show that all respondents who have been well implemented mix farming agribusiness management may indirectly obtain the economic benefits, especially to the staple food providers of rice since those respondents generally first sell their mix farming agribusiness yields in order to purchase rice. Thus, the farmers should improve their awareness on the functions of practical and economic benefits that food sustainability in agro-tourism village areas may be well implemented.
\end{abstract}

Keywords: Agro-Tourism Areas, Farmers, Food Sustainability, Mix Farming Benefit.

This is an open access article under Creative Commons Attribution 4.0 License.

\section{Introduction}

Food is one major need of an individual which may not be delayed due to the human rights in determining the quality of human resources. Thus, food problems, both in micro and macro level, have become one priority of thesustainable national development programs. The fulfillment of food needs due to the quantity, quality, nutrient, or security aspects are the pillars regarding to theformation of qualified human resources to improve the competitiveness of Indonesian people in international level

\footnotetext{
${ }^{1}$ Prof. Sociology, Faculty of Social and Political Sciences, Jenderal Soedirman University

2 Department of Agronomy, Faculty of Agricultural, Jenderal Soedirman University, Corresponding author E-mail: Scokronegoro@yahoo.com
} 
(Suryana, 2004). However, some community groups are still threatened and suffer from the food shortage. One of those community groups is the poorfarmer householdsin villages.

Food shortage experienced by the poor farmer households is one complicated national problem due to the number of poor people in Indonesia which have already reached 28 million people (11.25\%) and most of them (more than 50 percent) live in villages either as poor farmers or traditional fishermen. However, the most important thing is the sustainable impact on poor farmer households which are easily suffer from the food shortage that eventually results in the next generations with less qualified human resources. The poor farmer households have a greatly limited capacity of: income, education, health, political participation, productivity, productive working opportunity, competitiveness, and more. Poor farmer households only have an opportunity to cultivate one plot of land with a greatly limited wide to develop their productive earning diversification. This effort is greatly potential to empower themselves to be free from various economic problems and food shortage. Thus, poor farmer households do not have an adequate security shutter when facing the food shortage, especially during the scarcity periods.Poor farmer communities living in agro-tourism areas are categorized into groups experiencing the dilemmatic socioeconomic problems regarding to the food shortage. One recently revealed dilemmatic socioeconomic problem is that they have to allow half or all of their farm lands for the development of agro-tourism areas in their villages. In addition, the farmers should also face the facts that they have lost their main earning for livingthat lower their purchasing power. Drake (1991) revealed that tourism would be successful if it involves the active participation of the community. Selain melibatkan partisipasi maka satu hal yang perlu diperhatikan saat memberdayakan masyarakat petani terlebih dahulu mengidentifikasi karakteristik sosial ekonomi (Dumasari and Watemin,2013). Hal ini mendasar untuk memahami potensi sumberdaya diri dalam pengelolaan usaha yang produktif.

From the results of other studies cited that tourism has a positive impact on economic growth, but tourism stretches social cohesion (Wright, 2006; Lowry, 1999). However, in some villages this study is still found not yet integrated local natural environment with tropical potential. The contribution of tourism is still not optimal (Santosa and Priyana. 2010).The farmers' land function transfer to agrotourism areas results in poverty and chronic problems on food shortage. Salah satu solusi strategis untuk menyelesaikan persoalan ini yaitu membantu masyarakat petani untuk melakukan livelihood diversification. Upaya ini tentu tidak terlepas dari pengembangan strategi managemen untuk mengelola usaha yang memungkinkan meningkatkan produktivitas dan kreatifitas untuk pemberdayaan petani (Dumasari dan Rahayu, 2016). Hal penting lain yang tidak kalah penting yaitu adopsi inovasi untuk pengelolaan usaha pertanian berbasis wisata (Eneji,et.al., 2012 and Rogers, 1995).This condition may not last for a longer period. Thus, a potential and strategic effort is made to reduce the problem through the development of mix farming by utilizing the potential of local resources.Mix farming agribusiness may provide practical and economic benefits to strengthen food sustainability of poor farmer households at agro-tourism areas.

\section{Research method}

The research location is purposively determined at agro-tourism areas of Karangreja subdistrict, Purbalingga Regency, Central Java Province. The research location is selected based on consideration that the majority of people have the main earning for living patterns as farmers who cultivate mix farming. Based on the research results, Santoso and Priyono (2010) figure out that the majority (> 50 percent) of farmers are classified into poor (with the status as farming labors with poor earningdiversification, with the income average of less than Rp.600,000 per month and also receivethe fossil fuel compensation). This research is designed based on a case study method with both qualitative and quantitative approach.

The types of data collected consist of primary and secondary data. The data are collected through in-depth interview, observation, and secondary data analysis. The research population covers the entire poor farmer households living around the research location. The respondent data sources are taken with a purposive technique fulfilling the criteria as farmers who first implement mix farming agribusiness. The qualitative data are analyzed by utilizing simple statistical tabulation, scoring, and percentage. Interactive mode of analysis is also used to analyse this data (Miles and Huberman,1991) 


\section{Result and discussion}

Mix farming agribusiness has the superiority to support food sustainability in strengthening the poor farmer households in villages. The mix farming agribusiness pattern management is one productive effort alternative which is potential to be utilized by the farmers to achieve the agricultural product diversification that additional income may be obtained. Mix farming agribusiness is an integrated farming pattern in which farmers may cultivate various types of agricultural commodities on a plot of land with a greatly limited area.

The research respondents cultivate their mix farming agribusiness around their front, side, and back house yard area. 12 respondents are considered as the farmers who first implementMix farming agribusiness which consists of six types as presented in figure $\mathrm{I}$.

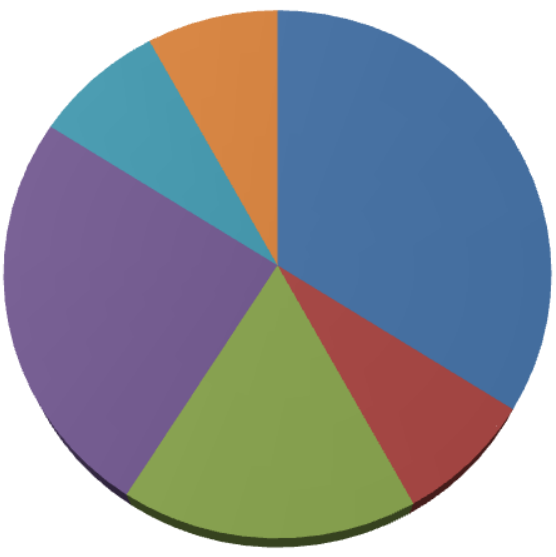

Type I. Various Types of Vegetables + Fresh Water Fish (Cat Fish)

Type II. Various Types of Vegetables + Fresh Water Fish + Crops (Corn)

Type III. Various Types of Vegetables + Herbal Plants + Fresh Water Fish (Cat Fish, Tilapia, Gourami)

Type IV. Various Types of Vegetables + Fresh Water Fish (Cat Fish) + Livestock (Chicken)

Type V. Various Types of Vegetables + Fresh Water Fish + Livestock (Chicken)

Type VI. Various Types of Vegetables + Herbal Plants + Fresh Water Fish + Livestock (Chicken and Goats)

Figure 1:Various mix farming agribusiness types managed by the respondents

Figure 1 above shows that 34 percent of respondents who first implement mix farming agribusiness are interested in the management of type I, in which the commodities are various types of vegetables and fresh water fish (cat fish). The respondents are interested in the management of mix farming type I due to: the production cost is very low and may be cultivated in the smallest cultivation area of $14-28 \mathrm{~m}^{2}$. The layout of mix farming agribusiness on vegetables and cat fish cultivation tend to be on a plot of land beside or at the back of the house.

The other reason dealing with the cultivation technique of various plants (spinach, mustard greens, spring onion, celery, red pepper, kale, long green bean, and tomatoes) and cat fish is because they are easily cultivated as well as the harvest failure is considered low. The respondents also figure out and implement the mix farming agribusiness type I due to its practical and economic benefits to strengthen the household food sustainability.

The most preferable mix farming agribusiness after type I isthat of type IV (25 percent of respondents) and type III (17 percent of respondents). Both mix farming types are implemented by those whose lands are wider than the first ones which are between $28-32 \mathrm{~m}^{2}$ wide. The layout of mix farming agribusiness on various types of vegetables, herbal plants, and fresh water fish cultivated based on the same plot of land. The cultivated fresh water ponds are more than 2 units located nearby, such as cat fish pond near tilapia or gourami pond. Beside the ponds, various vegetables and herbal plants (ginger, turmeric, galingale,and lemon grass) are planted.

Respondents, who cultivate chicken as their livestock, locate the chicken houses in two until three meters from the fish ponds. The mix farming agribusiness type II, V, and $\mathrm{VI}$ are implemented by a total respondent of respectively 8 percent. Theyadmit thatthe implementation ofthose three mix farming agribusinessesrequire higher production cost.

Similarly to the first implementers of mix farming agribusiness type I, those implementing mix farming agribusiness type II, III, IV, V, and VI also explain their fundamental reasons related to their 
interest in managing this integrated agricultural pattern due to its practical and economic benefits to strengthen the family food sustainability.

Good management of mix farming agricultural business has proven, either directly or indirectly, strengthening the respondents' family food sustainability. The respondents explain that mix farming has both practical and economic benefits to strengthen their family food sustainability. Those benefits are presented in table 1.

Table 1: Some mix farming's practical and economic benefits to strengthen the respondent households' food sustainability

\begin{tabular}{|c|c|c|c|c|c|}
\hline No. & Activity & Benefit & & & \\
\hline & & Practical & & Econor & \\
\hline & & Direct & Indirect & Direct & Indirect \\
\hline 1. & Harvesting the yields for family food consumption & $\checkmark$ & & & \\
\hline 2. & $\begin{array}{l}\text { Sharing the yields for food materials of the neighbors } \\
\text { and relatives }\end{array}$ & $\checkmark$ & & & \\
\hline 3. & $\begin{array}{l}\text { Utilizing the yields to produce the processed food } \\
\text { products for self consumption and to sell at the stalls of } \\
\text { the surrounding village areas. }\end{array}$ & $\checkmark$ & $\checkmark$ & & $\checkmark$ \\
\hline 4. & Utilizing the yields for family herbal medicine materials & & $\checkmark$ & & \\
\hline 5. & Selling some of the yields to & & & $\checkmark$ & \\
\hline 6. & Mix farming waste management for feed and fertilizer & & $\checkmark$ & & $\checkmark$ \\
\hline 7. & $\begin{array}{l}\text { Exchanging the yields with the neighbors'/ relatives' to } \\
\text { complete their family food materials. }\end{array}$ & $\checkmark$ & & & \\
\hline 8. & $\begin{array}{l}\text { Utilizing yields for the seeds of the next mix farming } \\
\text { agribusiness (self belonging and a part of it is shared to } \\
\text { the neighbors/relatives. }\end{array}$ & $\checkmark$ & & & \\
\hline 9. & $\begin{array}{l}\text { Selling the plant seedling and cat fish seed to purchase } \\
\text { rice and side dishes }\end{array}$ & & & & $\checkmark$ \\
\hline
\end{tabular}

Source: processed primary data, 2015

Table 1 above shows that the mix farming's practical and economic benefits have either direct or indirect influence on respondent households' food sustainability strengthening. The levels of mix farming's practical benefits on each activity intended to strengthen the respondent households' family food sustainability are various. Those differences are presented in table 2.

The practical benefits which respondents may directly obtain are due to the generated mix farming yields that those may be readily consumed by their household members. Mix farming implementation enables respondents to provide more complete food materials in their households, including vegetables and side dishes with animal nutrient contents, especially from cat fish. Thus, activities in utilizing the mix farming yields may directly fulfill the consumption need with higher practical benefits to strengthen respondents' family food sustainability (Ariani, et.al. 2008)

Some respondents acknowledge that the production of mix farming agribusiness may also provide significant practical benefits in strengthening food sustainability of the neighbors and relatives. Neighbors and relatives also frequently take a part in harvesting the vegetables cultivated by the respondents. During cat fish harvest periods, the respondents also share them to their neighbors and relatives. The activities of sharing a part of the cat fish harvest to the neighbors and relatives for their food supply have high practical benefits.

The other activities which have higher but indirect practical benefits are the utilization of mix farming yields as raw materials in processing various products made by the respondents to be sold at the traditional stallsof the surrounding villageareas. The relatively high connectivity bond among respondents encourages them to exchange their yields to complete their family food materials. Thus, these activities may also beconsidered having high practical benefits. 
Exchange of yields for households' food material supplies

Production input raw materials (feed, solid and liquid fertilizers) from mix farming agribusiness wastes

Household herbal medicine materials

Raw material of processed food products

Reserved food materials for the consumption of neighbors/relatives

Consumption food for household members

Description:

z 7 Very High; 5-6, 9 High; 3-4, 9 Moderate, < 3 Low

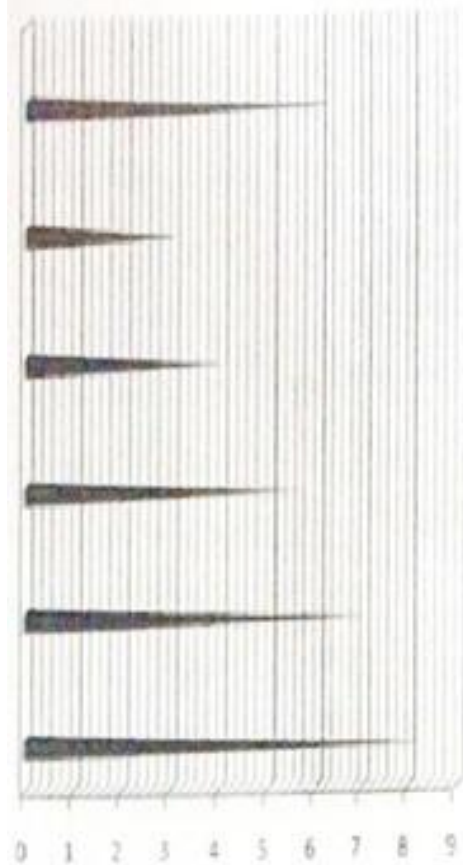

Practical Benefit Level

Figure 2:Mix farming's practical benefitlevelto strengthen the respondenthouseholds' food sustainability

Several respondents state that they have put into functionthe mix farming yieldswhich are classified into herbal plants as the households' herbal medicine materials. Therefore, the respondents consider that this activityhave moderate level of practical benefits because it cannot directly strengthen food sustainability of respondent households.

Another activity that provides practical benefits but at low level is processing of several types of mix farming waste to produce animal feed and plant fertilizer, either liquid or solid. Several practical benefits of mix farming agribusiness that have supported to strengthen food sustainability of respondenthouseholds tend to be seasonal. Thus, the respondents need to arrange planting season on several types of commodity, especially vegetables and corn, not to be harvested simultaneously.

From the availabilityperspective on types of food materials, it is found that high practical benefits are directly observed from ease of 83 percent of respondents in preparing food of vegetable and side dish (cat fish).

In addition, the development of mix farming agribusiness also provides direct practical benefits to 67 percent of respondents in obtaining food types of corn and chicken. Food types of Mozambique tilapia, gourami, herbal plants and goat categories only provide practical benefits to 33 percent of respondents.

The management of mix farming agribusiness has provided economic benefit to respondents, either directly or indirectly. Several activities indicating economic benefit of mix farming to strengthen food sustainability of respondents' household have different levels. According to respondents' explanation, activity with very high level of economic benefit is when they sell in part yields to purchase rice and side dish.

As for other activities related to economic benefit of mix farming agribusiness respondents consider as of high category in strengthening food sustainability of household is to sell plant seedling and cat fish seeds to purchase basic food needs (rice) and side dish. In Figure 3, the difference in level of economic benefits of mix farming is observed. 
To sell plant seedling and cat fish seeds to purchase rice and side dish

To process mix farming waste for feed and fertilizer

To sell a part of yields to purchase rice and side dish

To utilize yields to produce processed food products to sell for customers (stalls) in surrounding village areas

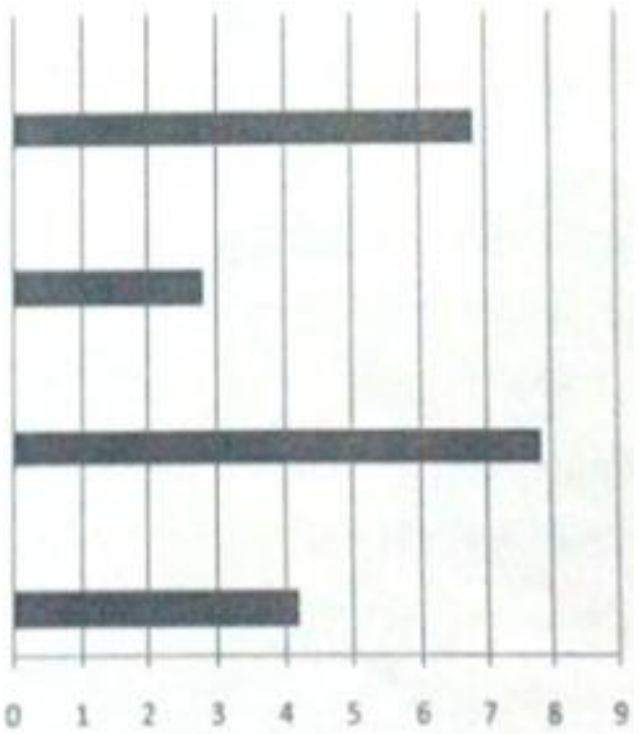

Description:

Economic Benefit Level

z 7 Very High; 5-6, 9 High; 3-4, 9 Moderate, < 3 Low

Figure 3:Mix farming's economic benefit level to strengthen the respondenthouseholds' food sustainability

Activity indicating that the respondents utilize yields to produce processed food products for sale to customers (stalls) in surrounding village areas has moderate level of economic benefits. Products produced are various cakes bread, and chips. The respondents explain that the low economic benefit level include activities on mix farming waste management activities to make fish and livestock feed as well as plant fertilizers. Some respondents have already performed chicken and goats livestock waste management into manure either solid or liquid. Some other respondents are able to produce compost fertilizer made of plant waste/residue. In addition, the farmers joining certain agricultural group are able to manage the cow manure wastes into biogas as the bio-energy for the other groups of farmers that independency on energy may be achieved (Santoso, 2014).

The mix farming agribusiness utilization found at agro-tourism areas of Karangreja is in facts potential to become the alternative solution on the decreasing areas of the lands experienced by the respondents and other farmers due to the impacts on losing the main earning and food shortage. However, the mix farming's practical and economic benefits should be independently managed by the respondents to fulfill their family needs on food during a season. The utilization of narrow lands at the respondents' house yards for mix farming is basically not only to strengthen food sustainability but also when this type of agribusiness is intensively developed may have the strategic values as the superior products for agro-tourism markets in Karangreja.

The mix farming practical and economic benefits to strengthen the respondents' food sustainability are the results of community empowerment processes based on local resources at agrotourism areas as stated by Santoso and Priyono (2012). The mix farming agribusiness' practical and economic benefits obtained by the respondents at agro-tourism areas of Karangreja is due to their awareness to safe some of their yields to fulfill their family food and nutrition consumption needs. Basically, it is to prevent them from food shortage due to the contradictive roles as stated by Arianiet al. (2008) that on one side, the poor farmers are the producers of food materials, yet on the other hand, they also become the consumers who can't afford to purchase their own food materials as they sell all their yields during the harvest to fulfill their daily needs. In this context, the author argues that the farmers have been in different condition with that stated by Scott (1976) stating that the poor farmers seem to live close to the dangerous zone (danger zone) and tend to avoid risk (risk averse) without maximizing the profits (non profit maximization). The eco-techno entrepreneurship supports in mix farming agribusiness also improve the poor farmers' competence in maintaining the survival behaviors at agro-tourism areas (Santoso and Iqbal, 2013). 


\section{Conclusion}

Good management of mix farming agribusiness may provide practical and economic benefits to strengthen food sustainability of the poor farmers who are considered as the respondents of this research at the agro-tourism areas of Karangreja. Mix farming practical and economic benefit level is different in providing opportunities for respondents to strengthen their family food sustainability. However, it is necessary to concern that the mix farming practical and economic benefits to strengthen food sustainability of farmer households are still temporal and last only during the harvest time. It is found that the respondents have already owned awareness to equalize the productive behaviors for the economic interests and survival behaviors to strengthen their family food sustainability living at the agro-tourism areas.

Various real efforts have been made and are still necessary to make in order to optimize the mix farming practical and economic benefits to strengthen food sustainability of the poor farmer households at the agro-tourism areas of Karangreja. Respondents' ability to manage the rotation of plant, fish, livestock, and herbal plants in mix farming agribusiness is greatly necessary to guarantee the availability of food materials during the season.

\section{Acknowledgements}

Authors are very grateful to Directorate of Research and Social Service, KEMRISTEKDIKTI for necessary fund provided. Without this, The research can't be implemented. Appreciation goes to Dumasari (My beloved wife) and Mr. Kariadi and also Dinda Dewi Aisyah, my daughter, who help me fortranslating this manuscript.

\section{References}

Ariani, Mewa, Erwidodo and adreng Purwoto. (2008).The Direction of Food Diversification: A Study on Level of Participation, Rice Consumption, and Other Carbohydrate Sources. Research Result Report Provided toSocial and Economic Research Center on Agriculture. Research and Development Office. Department of Agriculture. Bogor. pp. 5-30.

Drake,S. (1991). Local Participation in Local Tourism Projects. Taken From T. Whelan. Nature Tourism: Managing For The Environment. Island Press. Washington DC.

Dumasari and Watemin (2013). Karakteristik Sosial Ekonomi Petani Miskin dalam Pengelolaan Usaha Mikro Tourism Souvenir Goods. Mimbar: The Journal of Social and Development 29 (2) 205-2014

Dumasari dan Tri Septin Rahayu, (2016). Managemen Strategy of Creative Souvenir Micro Enterprise For The Empowerment of Craftsment Peasant. Mimbar: The Journal of Social and Development 32 (1). 175-186

Eneji, Mathias Agri, Song Weiping, Oko Sylvannus Ushie. (2012). Benefit of Agricultural TechnologyInnovation Capacity to Peasant Farmers in Rural Poor Areas: The Case of DBN Group, China. International Journal of Development and Sustainability. Vol 1 (2) 145-170

Lowry L., (1999). Recreation and Agricultural Tourism: New Market For Rural Community. Journal of Vocation Marketing (3)1, 5-10

Miles, M.B., and A. M., Huberman, (1991). Designing Qualitative Research. Mac Graw Hill Company. New York.

Rogers, Everett M (1995). Diffusion of Innovations. The Free Press. London.

Santosa, I and Rawuh EdyPriyono. (2010). Empowerment of Villagers Through Agro-tourism Management Based on Local Resources. Stage III Hibah Kompetensi Research Result Report.Higher Education-Research and Community Service Institution of Jenderal Soedirman University. Purwokerto. Pp. 18-34

Santosa,I dan Rawuh Edi Priyono. (2012). Dissemination of Empowerment of Villagers Through Agrotourism Management). Published by Mimbar Journal, Social and Development Journal.Bandung Islamic University. Bandung.. 28 (2). Pp 181-190

Santosa, I and Achmad Iqbal. (2013). A Model of Empowerment of Villagers Through Mix Farming Productive Business Management by Utilizing Eco-techno Entrepreneur at Agro-tourism areas. Stage I National Strategic Research Result Report). Higher Education-Research and Community Service Institution of Jenderal Soedirman University. Purwokerto.pp. 5-18 
Santosa, I. (2014). Strategic Management of Rural Community Empowerment: Based Local Resources. Paper Contributed at $3^{\text {rd }}$ of ICPM August 18-19, Grand Kuta. Denpasar. Proceeding of International Conference on Public Management. Atlantis Press. Paris. France.

Scott, James C. (1976). The Moral Economy of the Peasant, Rebellion, and Subsistence in Southeast Asia. Yale University Press. Ltd. New haven and London.

Suryana, Achmad. (2004). Food Sustainability in Indonesia. in Food and Nutrition Sustainability in Regional Autonomy and Globalization Era. WNPG. Indonesian Scientific Institution. Jakarta.

Wright,S.E. (2006) The Socio Cultural Impact of Ecotourism on The Indigeneous Peoples of The Wakatobi Marine National Park. Downloaded from http://www.opwal.com/Indonesia 